Lingua Rima: Jurnal Pendidikan Bahasa dan Sastra Indonesia

Vol. 11 No. 1 Januari 2022

http://jurnal.umt.ac.id/index.php/lgrm

\title{
WACANA BERITA KURIKULUM OPERASIONAL SEKOLAH DI SEKOLAH PENGGERAK PADA KORAN DIGITAL RADARSOLO.JAWAPOS.COM (ANALISIS WACANA KRITIS MODEL TEUN A. VAN DIJK)
}

\author{
Desy Rufaidah ${ }^{1}$ \\ Pascasarjana UNS; Universitas Sarjanawiyata Tamansiswa ${ }^{1}$ \\ desy.rufaidah@ustjogja.ac.id ${ }^{1}$ \\ Ermawati $^{2}$ \\ Pascasarjana UNS; Universitas Sarjanawiyata Tamansiswa² \\ ermawati@ustjogja.ac.id ${ }^{2}$ \\ Sumarlam $^{3}$ \\ Pascasarjana UNS \\ sumarlam@staff.uns.ac.id
}

\begin{abstract}
ABSTRAK
Saat ini berita tidak hanya disajikan dalam bentuk cetak, tetapi disajikan pula dalam bentuk digital,daring. Melalui berita, komunikator dapat menyampaikan informasi, menyosialisasikan, mengampanyekan, memengaruhi, mengintimidasi, dan menanamkan ideologi kepada partisipan (pembaca). Makna dari wacana dan proses produksi berita dapat diketahui dengan analisis model Teun A. Van. Penelitian ini bertujuan untuk mendeskripsikan struktur teks dan konteks sosial model Teun A. Van Dijk pada wacana teks berita daring radarsolo.jawapos.com dengan judul "Sekolah Penggeran di Solo Kebut Rancang Kurikulum Baru". Berita tersebut diterbitkan 13 Juli 2021. Data penelitian ini berupa penggalan berita daring berjudul "Sekolah Penggeran di Solo Kebut Rancang Kurikulum Baru". Sumber data diperoleh dari surat kabar daring radarsolo.jawapos.com. Metode simak, teknik simak bebas libat cakap, catat, dan studi Pustaka digunakan untuk mengumpulkan data. Instrumen penelitian yaitu pemahaman peneliti mengenai AWK model Teun A. Van Dijk dan sekolah penggerak dengan kartu data. Keabsahan data dilakukan dengan triangulasi teknik. Metode analisis data menggunakan metode analisis wacana kritis model Teun A. Van Dijk. Hasil penelitian ditemukan bahwa struktur teks berita tersebut memuat tiga dimensi teks yaitu struktur makro, superstruktur, struktur mikro. Struktur makro yaitu sekolah penggerak harus menggunakan Kurikulum Operasional Sekolah. Superstruktur meliputi meliputi bagian summary dan story, sedangkan struktur mikro meliputi latar, detil, koherensi, bentuk kalimat, leksikon, dan grafis. Dalam konteks sosial diketahui tidak terdapat praktik kekuasaan dan akses luas.
\end{abstract}

Kata kunci: Kurikulum Operasional, Analisis Wacana

\section{A. PENDAhULUAN}

Sekolah penggerak merupakan salah satu program Menteri Pendidikan dan Kebudayaan, Riset dan Teknologi pada tahun 2021. Tidak semua sekolah tergolong sekolah penggerak, tetapi setiap jenjang pendidikan ada perwakilan sekolah yang menjadi sekolah penggerak. Lulusan sekolah penggerak diharapkan untuk memiliki profil pelajar pancasila. Profil pelajar pancasila meliputi bernalar kritis, kreatif, mandiri, beriman, bertakwa kepada Tuhan YME, dan berakhlak mulia, bergotong royong, dan berkebhinekaan global. Hal itu untuk 


\section{Lingua Rima: Jurnal Pendidikan Bahasa dan Sastra Indonesia \\ Vol. 11 No. 1 Januari 2022 \\ http://jurnal.umt.ac.id/index.php//grm}

mendukung visi pendidikan Indonesia yakni mewujudkan Indonesia maju yang berdaulat, mandiri, dan berkepribadian. Beberapa sekolah di Solo termasuk sekolah penggerak.

Peristiwa tersebut disusun menjadi suatu wacana di surat kabar. Wacana adalah satuan bahasa terlengkap yang dinyatakan secara lisan dan tertulis, wacana lisan seperti pidato, ceramah, khutbah, dan dialog, sedangkan wacana tertulis yang dilihat dari bentuknya bersifat kohesif, dari segi makna bersifat koheren, terpadu (Sumarlam, 2013: 30). Beberapa sekolah di Solo terlibat dalam program sekolah penggerak yang sedang digalakkan. Wacana tersebut disajikan dalam ragam tulis yang diterbitkan di surat kabar. Dalam surat kabar disusun realitas dari berbagai peristiwa yang terjadi menjadi suatu wacana yang bermakna (Badara, 2012: 8).

Pengetahuan dan pengalaman penulis berita (komunikator) dalam surat kabar memengaruhi wacana yang dihasilkan. Wacana yang dihasilkan mengandung makna yang ingin disampikan komunikator kepada partisipan. Ada kalanya wacana yang dihasilkan cenderung tidak netral sehingga terkesan memengaruhi persepsi masyarakat. Namun, ada pula berita yang mendukung kebijakan atau peristiwa yang sedang terjadi sehingga terkesan mengampanyekan, menyosialisasikan suatu kebijakan. Keberpihakan wacana terlihat dari cara komunikator menyampaikan. Oleh karena itu, diperlukan analisis wacana kritis untuk dapat menyibak makna yang terkandung dalam wacana.

Radarsolo.jawapos.com merupakan salah satu media daring yang memublikasikan wacana pendidikan area Solo. Wacana mengenai sekolah penggerak menjadi salah satu topik pembicaraan publik dan dimuat di radarsolo.jawapos.com berjudul "Sekolah Penggeran di Solo Kebut Rancang Kurikulum Baru”. Peristiwa penyusunan kurikulum baru secara cepat terjadi di Solo. Narasumber dalam berita yaitu Sri Sayekti, Kepala Sekolah SD Muhammadiyah 1 Ketelan. Sekolah tersebut merupakan salah satu sekolah penggerak di Solo yang sedang menyusun kurikulum baru yaitu Kurikulum Operasional Sekolah. Berita dipublikasikan pada 13 Juli 2021. Wacana tersebut dianalisis dengan model analisis Teun A. Van Dijk. Analisis Teun A. Van Dijk tidak hanya melihat struktur teks, tetapi menganalisis bagaimana teks diproduksi dengan analisis kognisi dan konteks sosial (Eriyanto, 2001: 225). Lebih lanjut dijelaskan struktur teks meliputi struktur makro, superstruktur, dan struktur mikro. 
Lingua Rima: Jurnal Pendidikan Bahasa dan Sastra Indonesia

Vol. 11 No. 1 Januari 2022

http://jurnal.umt.ac.id/index.php//grm

\section{B. METODOLOGI PENELITIAN}

Jenis penelitian ini merupakan penelitian analisis wacana kritis dengan pendekatan analisis wacana kritis Teun A. Van Dijk. Analisis wacana kritis merupakan teori dan metode yang dapat mengkaji secara empiris hubungan wacana dengan perkembangan sosial dan kultural (Jorgensen dan Louise, 2010). Data dalam penelitian ini berupa penggalan berita daring yang berjudul "Sekolah Penggeran di Solo Kebut Rancang Kurikulum Baru". Data diperoleh dari surat kabar daring radarsolo.jawapos.com yang diterbitkan pada 13 Juli 2021. Data dikumpulkan dengan metode simak, teknik simak bebas libat cakap, catat, dan studi pustaka. Mahsun (2005: 92) menyatakan bahwa metode simak tidak hanya berkaitan dengan bahasa lisan, tetapi termasuk penggunaan bahasa tulis. Dalam teknik simak libat cakap, peneliti tidak terlibat dalam peristiwa tutur. Pada teknik catat, peneliti mencatat data hasil identifikasi pada kartu data kemudian dianalisis. Studi pustaka dilakukan dengan mencari informasi terkait sekolah penggerak dan kurikulum operasional sekolah. Instrumen penelitian berupa penguasaan peneliti tentang hal-hal yang berkaitan dengan analisis wacana kritis Teun A. Van Dijk dan sekolah penggerak. Selain itu, digunakan kartu data untuk membantu pencatatan data deskripsi analisis teks. Keabsahan data penelitian ini yaitu triangulasi teknik. Triangulasi teknik dilakukan untuk mengumpulkan data dari sumber data dengan teknik yang berbeda-beda. Data yang telah terkumpul dianalisis dengan kerangka analisis Teun A. Van Dijk. Penelitian ini menganalisis dimensi teks dan konteks sosial.

Tabel Metode Analisis Teun A. Van Dijk

\begin{tabular}{|l|l|l|}
\hline \multicolumn{1}{|c|}{ Dimensi } & \multicolumn{1}{c|}{ Tahap } & \multicolumn{1}{c|}{ Metode } \\
\hline Teks & Analisis deskripsi tekstual & Analisis Teks \\
\hline Kognisi Sosial & $\begin{array}{l}\text { Analisis bagaimana kognisi } \\
\text { komunikator (wartawan) } \\
\text { terhadap suatu peristiwa }\end{array}$ & Wawancara mendalam \\
\hline Konteks Sosial & $\begin{array}{l}\text { Analisis bagaimana wacana } \\
\text { berkembang di masyarakat }\end{array}$ & Studi pustaka \\
\hline
\end{tabular}

\section{HASIL PENELITIAN DAN PEMBAHASAN}

\section{Struktur Teks dalam Berita}

a. Struktur Makro dalam Berita 
Lingua Rima: Jurnal Pendidikan Bahasa dan Sastra Indonesia

Vol. 11 No. 1 Januari 2022

http://jurnal.umt.ac.id/index.php/lgrm

Pada struktur makro mengamati tema atau topik yang dikedepankan komunikator (Eriyanto, 2015: 228). Topik menggambarkan konsep, gagasan dominan (Jamaludin, Ermanto, dan Novia, 2016). Topik tersebut disusun dari subtopik-subtopik yang saling terkait mendukung topik. Subtopik yang digunakan komunikator/wartawan secara keseluruhan dapat membentuk wacana yang koheren dan utuh sehingga dapat mendukung topik berita.

Media berita daring radarsolo.jawapos.com pada 26 September 2021 terkesan memberikan penguatan pentingnya penyusunan kurikulum tersebut untuk dapat segera diselesaikan. Media berita tersebut digunakan untuk menyosialisasikan adanya kurikulum pendamping Kurikulum 2013 di sekolah penggerak, akan segera diselesaikan dan dilaksanakan. Struktur makro dalam berita daring tersebut menunjukkan sekolah penggerak harus menggunakan Kurikulum Operasional Sekolah sehingga kurikulum tersebut harus segera diselesaikan. Hal tersebut dapat dilihat pada data berikut ini.

Data SMa 1

Sekolah penggerak mengajak seluruh satuan pendidikan untuk berkomitmen memajukan ekosistem pendidikan yang lebih baik. Yakni dengan melahirkan agen-agen perubahan yang berpusat kepada siswa, berkemajuan, berkeunggulan, dan memiliki adab luhur. Selain itu, sekolah penggerak juga harus menggunakan kurikulum operasional sekolah (KOS), pendamping Kurikulum 2013 (K-13).

Data SMa 2

Ada beberapa prinsip pengembangan kurikulum operasional sekolah di sekolah penggerak.

Pada data SMa 1 menunjukkan koherensi global yang mendukung tema berita. Penggunaan data SMa 1 menunjukkan maksud komunikator yaitu sekolah penggerak diharuskan untuk menggunakan Kurikulum Operasional Sekolah. Supaya dapat segera digunakan, kurikulum tersebut harus segera diselesaikan. Pada data SMa 2, komunikator mengungkapkan prinsip-prinsip penyusunan Kurikulum Operasional Sekolah. Pada subtopik ini dijelaskan tentang prinsip penyusunan Kurikulum Operasional Sekolah meliputi berpusat kepada peserta didik, kontekstual, esensial, akuntabel, serta melibatkan komite satuan pendidikan dan stakeholder.

\section{b. Superstruktur dalam Berita}


Superstruktur berkaitan dengan alur berita dari awal sampai akhir yang membentuk kesatuan arti (Eriyanto, 2015: 232). Pada superstruktur terbagi menjadi summary dan story (Dijk, 1988: 55). Lebih lanjut dijelaskan jika summary meliputi headline dan lead, sedangkan story meliputi situasi dan komentar. Pada bagian summary, komunikator menampilkan tema yang ingin disampaikan sehingga dapat dikatakan bagian yang penting. Bagian story merupakan isi berita secara keseluruhan. Isi berita berupa gambaran keadaan suatu peristiwa dan komentar. Komentar dapat berasal dari narasumber yang dikutip wartawan dan simpulan wartawan terhadap pernyataan yang disampaikan narasumber.

Data Ss 1

Summary

Judul: Sekolah Penggerak di Solo Kebut Rancang Kurikulum Baru

Lead: SOLO - Beberapa sekolah di Kota Solo ditetapkan sebagai sekolah penggerak. Sekolah penggerak mengajak seluruh satuan pendidikan untuk berkomitmen memajukan ekosistem pendidikan yang lebih baik. Yakni dengan melahirkan agen-agen perubahan yang berpusat kepada siswa, berkemajuan, berkeunggulan, dan memiliki adab luhur. Selain itu, sekolah penggerak juga harus menggunakan kurikulum operasional sekolah (KOS), pendamping Kurikulim 2013 (K-13).

Pada data Ss 1 menunjukkan cara komunikator untuk memberikan penegasan bahwa Kurikulum Operasional Sekolah harus segera diselesaikan. Pada lead dijelaskan salah beberapa sekolah penggerak di Solo berkomitmen untuk menggunakan Kurikulum Operasional Sekolah. Komitmen tersebut dalam rangka memajukan ekosistem pendidikan yang lebih baik. Melalui berita ini, komunikator bermaksud untuk menginformasikan jika Kurikulum Operasional Sekolah dapat memperbaiki pendidikan. Diharapkan dapat segera digunakan di sekolah penggerak sehingga Kurikulum Operasional Sekolah harus segera diselesaikan. Dengan demikian, tergambar di mata publik bahwa Kurikulum Operasional Sekolah penting dan diterapkan di sekolah penggerak. Akan tetapi, tidak tidak dipaparkan penyebab seberapa esensial pengembangan kurikulum tersebut.

Story:

Data Ss 2

Ada beberapa prinsip pengembangan Kurikulum Operasional Sekolah di sekolah penggerak.

Data Ss 3

Menurut Kepala SD Muhammadiyah 1 Ketelan Sri Sayekti, pendidikan merupakan bagian kebudayaan. Sedangkan, saat ini teknologi digital telah menggerus nilai-nilai kebudayaan dengan cepat. 
Data Ss 4

Sri menyebutkan beberapa prinsip pengembangan Kurikulum Operasional Sekolah di sekolah penggerak. Di antaranya berpusat pada peserta didik. Yaitu pembelajaran yang harus memenuhi keragaman potensi, kebutuhan perkembangan dan tahapan belajar, serta kepentingan peserta didik.

Data Ss 5

Prinsip selanjutnya, kontekstual yang menunjukkan ciri khas dan karakteristik satuan pendidikan. Lalu konteks sosial budaya dan lingkungan. Serta dunia kerja dan industri (khusus SMK), termasuk menunjukkan karakteristik atau kekhususan peserta didik berkebutuhan khusus (khusus SLB).

Data Ss 6

Berikutnya akuntabel yang dapat dipertanggungjawabkan. Karena berbasis data dan aktual. Jadi, data yang digunakan tidak sembarangan. Selain itu, pengembangan Kurikulum Operasional Sekolah melibatkan komite satuan pendidikan dan berbagai stakeholder. Antara lain orang tua, organisasi, dan berbagai sentra.

Data Ss 7

Termasuk dunia industri dan dunia kerja (DUDI) untuk SMK. Di bawah koordinasi dan supervisi dinas pendidikan (disdik) atau kantor kementerian yang menyelenggarakan urusan pemerintahan di bidang agama, sesuai kewenangannya.

Data superstruktur di atas dipaparkan dalam story. Isi berita dari data-data di atas berupa simpulan komunikator (wartawan) bahwa dalam penyusunan Kurikulum Operasional Sekolah ada beberapa prinsip yang perlu diperhatikan. Prinsip Kurikulum Operasional Sekolah meliputi berpusat pada siswa, kontekstual, akuntabel, adanya keterlibatan komite satuan sekolah dan stakeholder serta berkarakter profil Pancasila. Kurikulum Operasional Sekolah dapat mengatasi permasalahan tergerusnya nilai-nilai kebudayaan. Prinsip-prinsip di atas perlu dipahami dalam proses penyusunan. Dari data-data tersebut, tercermin jika komunikator menganggap Kurikulum Operasional Sekolah perlu disusun dengan menjabarkan prinsip-prinsip penyusunan. Prinsip tersebut perlu diperhatikan supaya kurikulum yang dihasilkan sesuai dengan harapan.

Data Ss 8

"Sementara itu, kurikulum merupakan seperangkat rencana dan pengaturan mengenai tujuan, isi, dan bahan pelajaran. Serta cara yang digunakan sebagai pedoman penyelenggaraan kegiatan pembelajaran untuk capai tujuan pendidikan tertentu (UU Sisdiknas, 2003). Pemerintah pusat mulai menetapkan kerangka dasar dan struktur KOS," terangnya (Kepala SD Muhammadiyah 1 Ketelan Sri Sayekti) kepada Jawa Pos Radar Solo, kemarin

Data Ss 9

"Profil pelajar Pancasila, selalu menjadi rujukan dalam semua tahapan penyusunan KOS. Yakni bernalar kritis, kreatif, mandiri, beriman, bertaqwa 
kepada Tuhan YME, dan berakhlak mulia. Serta gotong royong dan berkebhinekaan global," imbuhnya.

Data Ss 10

"Kemudian esensial. Memuat semua unsur informasi penting atau utama yang dibutuhkan dan digunakan di satuan pendidikan. Bahasa yang digunakan lugas, ringkas, dan mudah dipahami," urainya.

Superstruktur pada data di atas terdapat dalam story yang berupa komentar narasumber. Pada story tersebut, komunikator memberikan penjelasan terkait apa itu kurikulum. Komentar narasumber mengatakan pemerintah pusat mulai menetapkan kerangka dasar dan struktur KOS, tetapi sekolah penggerak harus segera menyelesaikan pengembangan Kurikulum Operasional Sekolah. Idealnya kerangka dasar dan struktur ditetapkan terlebih dahulu, sebagai dasar pengembangan kurikulum. Hal tersebut menunjukkan adanya ketidaksesuaian dan terkesan proses pengembangan Kurikulum Operasional Sekolah kurang dipersiapkan dan dipaksakan.

\section{c. Struktur Mikro dalam Berita}

Hal yang diamati pada struktur mikro meliputi latar, setil, maksud, praanggapan, nominalisasi, sintaksis, stlisitika, dan retoris (Eriyanto, 2015: 228-229). Pada latar, komunikator akan membawa pandangan pembaca sesuai dengan pandangan atau pemikirannya. Wacana dalam berita daring radarsolo.jawapos.com yang berjudul "Sekolah Penggerak di Solo Kebut Rancang Kurikulum Baru” menginformasikan jika di Solo ada beberapa sekolah penggerak yang harus menggunakan kurikulum baru. Kurikulum tersebut yaitu Kurikulum Operasional Sekolah yang disusun secara mandiri oleh tiap satuan pendidikan. Oleh karena itu, perlu memerhatikan prinsip penyusunannya.

Dalam penulisan berita, komunikator mengolah informasi yang diperoleh dengan detil eksplisit atau pun implisit. Detil eksplisit berupa prinsip pengembangan Kurikulum Operasional Sekolah yang harus segera diselesaikan. Hal itu terkesan kurikulum tersebut sangat medesak untuk segera digunakan. Selain itu, detil implisit dalam berita yakni penyebab seberapa mendesak pengembangan Kurikulum Operasional Sekolah. Akan tetapi, tidak dipaparkan penyebab seberapa mendesak pengembangan kurikulum tersebut saat masih ada kurikulum yang sedang berjalan. Dengan demikian, tergambar di mata publik bahwa Kurikulum Operasional Sekolah 


\section{Lingua Rima: Jurnal Pendidikan Bahasa dan Sastra Indonesia \\ Vol. 11 No. 1 Januari 2022 \\ http://jurnal.umt.ac.id/index.php//grm}

sangat penting dan harus segera diselesaikan supaya dapat segera diterapkan di sekolah penggerak.

Fakta peristiwa yang terpisah-pisah dapat dihubungkan dengan konjungsi. Fakta-fakta peristiwa tersebut dapat menjadi satu kesatuan yang padu.

\section{Data SMi 1}

Yakni dengan melahirkan agen-agen perubahan yang berpusat kepada siswa, berkemajuan, berkeunggulan, dan memiliki adab luhur.

Data SMi 2

"Profil pelajar Pancasila, selalu menjadi rujukan dalam semua tahapan penyusunan KOS. Yakni bernalar kritis, kreatif, mandiri, beriman, bertaqwa kepada Tuhan YME, dan berakhlak mulia. Serta gotong royong dan berkebhinekaan global," imbuhnya.

Konjungsi dan menghubungkan antarklausa. Konjungsi tersebut menyatakan makna penambahan, sekolah penggerakan tidak hanya memajukan pengetahuan dan keterampilan peserta didik, tetapi berkomitmen untuk membekali nilai-nilai sikap sehingga menjadi peserta didik yang beradab. Konjungsi dan, serta menyatakan peserta didik di sekolah penggerak dengan Kurikulum Operasional Sekolah memiliki profil pelajar Pancasila yang tidak hanya bernalar kritis, kreatif, mandiri, beriman, bertaqwa kepada Tuhan YME, tetapi memiliki akhlak mulia (budi pekerti luhur) dan berjiwa sosial yaitu gotong royong dan berkebhinekaan global.

Tata bahasa yang digunakan dalam berita berupa kalimat aktif-pasif. Dalam kalimat aktif, subjek sebagai pelaku yang melakukan suatu tindakan dan diletakkan di awal kalimat. Ketika bentuk aktif, diubah ke dalam bentuk pasif. Pola tersebut berubah. Objek atau pihak yang dikenai tindakan menjadi pusat perhatian.

Data SMi 4

Beberapa sekolah di Kota Solo ditetapkan sebagai sekolah penggerak.

Data SMi 5

Sekolah penggerak mengajak seluruh satuan pendidikan untuk berkomitmen memajukan ekosistem pendidikan yang lebih baik.

Data SMi 6

Selain itu, sekolah penggerak juga harus menggunakan kurikulum operasional sekolah (KOS), pendamping Kurikulum 2013 (K-13).

Bentuk kalimat pada data SMi 4 berupa kalimat pasif, sedangkan data SMi 5 dan SMi 6 berbentuk kalimat aktif. Pada data SMi 4, subjek kalimat yakni beberapa sekolah di Kota Solo. Data SMi 5 dan SMi 6 berupa kalimat aktif. Pada data SMi 5 dan SMi 6 subjek kalimat yakni sekolah penggerak. Data SMi 4,5, dan 6 subjek kalimat diekspresikan secara eksplisit. Subjek tersebut yang difokuskan dan 
ditonjolkan komunikator. Data SMi 4 memfokuskan beberapa sekolah di Kota Solo, sedangkan data SMi 5 dan 6 menonjolkan sekolah penggerak. Data tersebut menginformasikan jika ada beberapa sekolah di Solo menjadi sekolah penggerak. Sekolah penggerak diminta untuk memiliki komitmen memajukan pendidikan dan menggunakan Kurikulum Operasional Sekolah sebagai pendamping Kurikulum 2013. Jika posisi subjek dijadikan objek pada kalimat pasif, akan menimbulkan kesan berbeda. Data SMi 4,5, dan 6 berbentuk kalimat deduktif sehingga pemfokusan dan penonjolan terlihat lebih jelas.

Data SMi 7

Sekolah penggerak mengajak seluruh satuan pendidikan untuk berkomitmen memajukan ekosistem pendidikan yang lebih baik.

Dalam KBBI daring (https://kbbi.kemdikbud.go.id/entri/ekosistem) ekosistem adalah keanekaragaman suatu komunitas dan lingkungannya yang berfungsi sebagai suatu satuan ekologi dalam alam; komunitas organik yang terdiri atas tumbuhan dan hewan, bersama habitatnya. Diksi ekosistem digunakan untuk menggambarkan bahwa sekolah penggerakan berupa ekosistem. Ekosistem tersebut terdiri atas kepala sekolah, wakil kepala sekolah, guru, karyawan, dan siswa menjadi satu habitat. Seluruh unsur di sekolah penggerak memiliki komitmen yang sama.

Data SMi 8

Yakni dengan melahirkan agen-agen perubahan yang berpusat kepada siswa, berkemajuan, berkeunggulan, dan memiliki adab luhur.

Dalam KBB daring (https://kbbi.kemdikbud.go.id/entri/agen) agen adalah orang atau perusahaan perantara yang mengusahakan penjualan bagi perusahaan lain atas nama pengusaha, perwakilan; kaki tangan. Agen pada data SMi 8 berarti siswa sekolah penggerak. Lulusan sekolah penggerak diharapkan untuk memiliki keunggulan dalam hal pengetahuan, keterampilan, dan berbudi pekerti luhur. Dengan demikian, lulusan tersebut dapat membawa perubahan Indonesia ke arah yang lebih baik.

Data SMi 9

Sekolah penggerak di Solo kebut Rancang Kurikulum Baru

Dalam KBBI daring (https://kbbi.kemdikbud.go.id/entri/kebut) kebut adalah jalankan dengan cepat. Pada data SMi 9 berarti perancangan, penyusunan kurikulum dilakukan secara cepat di sekolah penggerak. 
Lingua Rima: Jurnal Pendidikan Bahasa dan Sastra Indonesia

Vol. 11 No. 1 Januari 2022

http://jurnal.umt.ac.id/index.php//grm

Data SMi 10

SOLO - Beberapa sekolah di Kota Solo ditetapkan sebagai sekolah penggerak.

Pada data SMi 10, kata Solo dicetak tebal. Hal tersebut dikarenakan komunikator ingin memfokuskan perhatian partisipan ke kata yang dianggap penting. Kata Solo dianggap penting karena informasi yang disampaikan khusus berkaitan dengan Kota Solo. Sekolah penggerak yang dibicarakan dalam berita berarti sekolah penggerak di Kota Solo.

\section{Konteks Sosial}

Suatu wacana disusun berdasarkan peristiwa yang terjadi di masyarakat, seperti pendidikan, ekonomi, politik, kebudayaan, maupun sistem sosial masyarakat. Aspek sosial dalam berita menekankan permasalahan pendidikan. Pada tahun 2021 ada program sekolah penggerak dengan menggunakan kurikulum baru. Sekolah penggerak dilaksanakan berdasarkan Keputusan Menteri Pendidikan dan Kebudayaan, Riset dan Teknologi Nomor 162 Tahun 2021. Dengan terbitnya keputusan menteri tersebut, program sekolah penggerak resmi dilaksanakan. Namun, tidak semua sekolah menjadi sekolah penggerak, sekolah terpilih.

Sekolah di bawah Kementerian Pendidikan dan Kebudayaan, Riset dan Teknologi sehingga harus mematuhi aturan, ketentuan, dan program yang berlaku. Begitupun aturan penerapan kurikulum baru, semua sekolah penggerak menggunakan kurikulum baru yaitu Kurikulum Operasional Sekolah. Selain sekolah penggerak tetap menggunakan Kurikulum 2013. Peristiwa tersebut disampaikan komunikator dalam berita berjudul "Sekolah Penggeran di Solo Kebut Rancang Kurikulum Baru". Dalam berita, komunikator langsung membawa partisipan untuk menyetujui adanya program tersebut dengan menginformasikan dasar dalam penyusunan kurikulum baru.

Akan tetapi, tidak dijelaskan penyebab esensial kurikulum tersebut saat Kurikulum 2013 masih diterapkan. Konteks sosial berkaitan dengan ideologi dan kekuasaan yang dianut komunikator sehingga memengaruhi wacana yang diproduksi (Kasir, Muhammad, Ramli, Mohammad: 2021)

\section{Data KS 1}

Sekolah penggerak harus menggunakan kurikulum perasional sekolah (KOS), pendamping Kurikulum 2013 (K-13)

Pihak yang memiliki akses luas dapat cepat memperoleh informasi. Sekolahsekolah yang akan menjadi sekolah penggerak perlu mengikuti seleksi terlebih dahulu. 
Lingua Rima: Jurnal Pendidikan Bahasa dan Sastra Indonesia

Vol. 11 No. 1 Januari 2022

http://jurnal.umt.ac.id/index.php//grm

Namun, sekolah yang tidak memiliki akses luas tertinggal informasi sehingga tidak dapat mengikuti seleksi. Sekolah yang terlibat dalam program sekolah penggerak akan mendapatkan akses luas sehingga dapat cepat mendapatkan informasi terkait dengan program kementerian. Hal tersebut dikarenakan ada pendampingan seperti In House Training (IHT), informasi dari web (https://sekolah.penggerak.kemdikbud.go.id/), kegiatan workshop dari Kemdikbud yang diunggah di Youtube sehingga dapat disimak ulang.

\section{SIMPULAN DAN SARAN}

Model analisis wacana Teun A. Van Dijk pada penelitian ini mencakup dimensi teks dan konteks sosial. Dalam dimensi teks meliputi struktur makro, superstruktur, dan struktur mikro. Dalam berita daring berjudul "Sekolah Penggerak di Solo Kebut Rancang Kurikulum Baru” tidak terdapat praktik kekuasaan, tetapi akses kekuasaan luas.

\section{E. DAFTAR PUSTAKA}

Badara, Aris. (2012). Analisis Wacana: Teori, Metode, dan Penerapannya pada Wacana Media. Jakarta: Kencana.

Eriyanto. (2001). Analisis Wacana. Yogyakarta: PT LKiS Printing Cemerlang.

Dijk, Teun A. Van. 1988. News as Discourse. Hillsdale, New Jersey :Lawrence Erlbaum Associates, Inc.

Jamaludin, Asep, Ermanto, Novia Juita. 2016. "Tinjauan Analisis Wacana Kritis Perspektif Teun A. Van Dijk dalam Media Online Portal Harian Singgalang" dalam Jurnal Pendidikan Bahasa dan Sastra Indonesia, vol. 5, no. 2, seri A 7381 .

Jorgensen, Marianne W. and Louise J. Phillips. (2010). Discourse Analysis as Theory and Method (terj. Imam Suyitno, Lilik Wahyuni, dan Suwarna). Yogyakarta: Pustaka Pelajar.

Kasir, Muhammad, Ramli, Mohammad Harun. 2021. "Representasi Ideologi dalam ILC tvone Berdasarkan Struktur Mikro Analisis Wacana Kritis Model Teun A. Van Dijk" dalam Jurnal Kata, vo. 5, no. 1, hlm. 133-148.

Keputusan Menteri Pendidikan dan Kebudayaan, Riset dan Teknologi Nomor 162 Tahun 2021.

Mahsun. 2005. Metode Penelitian Bahasa. Depok: PT Rajagrafindo Persada.

Sumarlam. (2013). Teori dan Praktik Analisis Wacana. Surakarta: KATTA.

https://kbbi.kemdikbud.go.id

https://radarsolo.jawapos.com/pendidikan/13/07/2021/sekolah-penggerak-di-solo-kebutrancang-kurikulum-baru/ 